\title{
Increasing Literature And Sharia Financial Management Through The One BMT Housing Area Program In Banguntapan District Bantul In Yogyakarta
}

\author{
Ayif Fathurrahman, Yuli Utami \\ Program Studi Ekonomi Pembangunan, Fak. Ekonomi dan Bisnis UMY \\ ayif.fathurrahman@umy.ac.id
}

\begin{abstract}
The target of this PKM program is economically productive communities, namely people in housing in Banguntapan sub-district who have just established BMT covering aspects of marketing/socialization and management and accounting information systems (small businesses). The aim of the program is to develop an economically independent community with high literacy on syar'i transactions. Business partners in this program are BMTs that have just been established with a residential mosque base, namely BMT Sakinah, BMT Al-Anbiya and BMT Al-Huda. The problems faced by the three partners are: 1) Lack of competence and management in managing BMT, 2) Lack of legality, 3) Lack of Islamic financial literacy, so that BMT members still do not understand the function of BMT. As for the method of devotionare general lectures, short courses, tutorials and simulations. Materials that are focused on include the management and members of BMT: 1) Socialization of Transaction Contract applications legalized by the National Sharia Board, 2) Consolidating the understanding and application of Management Information Systems and Accounting Information Systems for BMT, for approximately eight months. The result of this dedicationis special assistance and provides BMT financial system software so that the BMT, BMT Sakinah (Puri Sakinah 2 Housing), BMT Al-Anbiya (Pesona Banguntapan Kotagede Housing) and BMT Al-Huda (Graha Banguntapan Housing) can manage accountably, professional and transparent. This program is expected to be able to facilitate the development of partner businesses so that they are able to provide a multiplier effect for housing-based BMTs and other newly established mosques.
\end{abstract}

Keywords: Housing BMT, Banguntapan, Transaction Agreement, SIA-BMT, SIM-BMT

\section{PRELIMINARY}

Banguntapan District is located in the northeast of the capital city of Bantul Regency. The area of Banguntapan District is $2.865 .9537 \mathrm{Ha}$. with details of rice fields covering an area of 1116 $\mathrm{Ha}$; Tegal/Dry/Garden land with an area of 1,528 Ha; Building area of $32 \mathrm{Ha}$; Other land area of $172 \mathrm{Ha}$. The administrative area of Banguntapan sub-district includes 8 villages, namely Banguntapan Village, Baturetno Village, Singosaren Village, Jagalan Village, Tamanan Village, Wirokerten Village, Potorono Village, Jambidan Village.

Banguntapan sub-district is located in the lowlands. The capital of the sub-district is at an altitude of 100 meters above sea level. The distance from the District Capital to the Central Government (Capital) of Bantul Regency is $15 \mathrm{Km}$. The expanse of the area in Banguntapan District is $100 \%$ in the form of a flat to choppy area. It is geographically located at $77^{\prime} 49^{\prime} 44^{\prime \prime}$ east longitude and 110' $24^{\prime} 30^{\prime \prime}$ south latitude with a position northeast of the capital city of Bantul Regency.

Directly adjacent to the capital city of Yogyakarta is a separate economic added value for Banguntapan, because it is close to the city center and strategic locations for government and trade. Thus, many housing developers read this situation with the possibility of widespread demand for quiet homes on the outskirts of the city. Since 2009 until now, cluster and semi-cluster housing has appeared near more than 100 houses with various classes and types, from class $D$ (lower) to class A (upper), from type 36 to type 150. 
The rampant housing growth is also balanced by the emergence of facilities around and within housing. Starting from the emergence of culinary centers, shops, hawker centers, fitness centers and swimming pools, early childhood schools, services, to supermarkets. This economic activity arose because of following demands, such as laundry service businesses, vegetable and basic food shops, culinary, beauty and fitness services and others, aligning industrial centers that are the mainstay of the Banguntapan sub-district's economy, such as: silver industry, furniture. , leather, chips, convection and agriculture.

Social activities such as RT, RW, Paguyuban, Arisan, Posyandu and similar activities, also raises the demand for the presence of savings and loan institutions. Seeing this phenomenon, an Islamic themed housing estate established a cooperative with Islamic contracts. The two-year trial showed encouraging developments. Thus, other housing estates are interested in holding similar sharia cooperatives. This is supported by the emergence of mosques in every housing estate and the condition of the Banguntapan sub-district which consists of more than $92 \%$ Muslims, so that the demand for Islamic transaction-based activities also increases.

The target of this PKM program is economically productive communities, namely people in housing in Banguntapan sub-district who have just established BMT covering aspects of marketing/socialization and management and accounting information systems (small businesses). The aim of the program is to develop an economically independent community with high literacy on syar'i transactions. Business partners in this program are BMTs that have just been established with a residential mosque base, namely BMT Sakinah, BMT AI-Anbiya and BMT Al-Huda.

\section{IMPLEMENTATION METHOD}

Outputfrom this service program later is the increasing skills of BMT officers in managing (soft skills and hard skills) and members have high literacy of BMT, so that members can optimize the existence of BMT in their environment and prosper their economic life. For this reason, an approach method is needed in the service of this partnership program. The methods used are Public Lectures, Short Courses and Tutorials and Simulations.

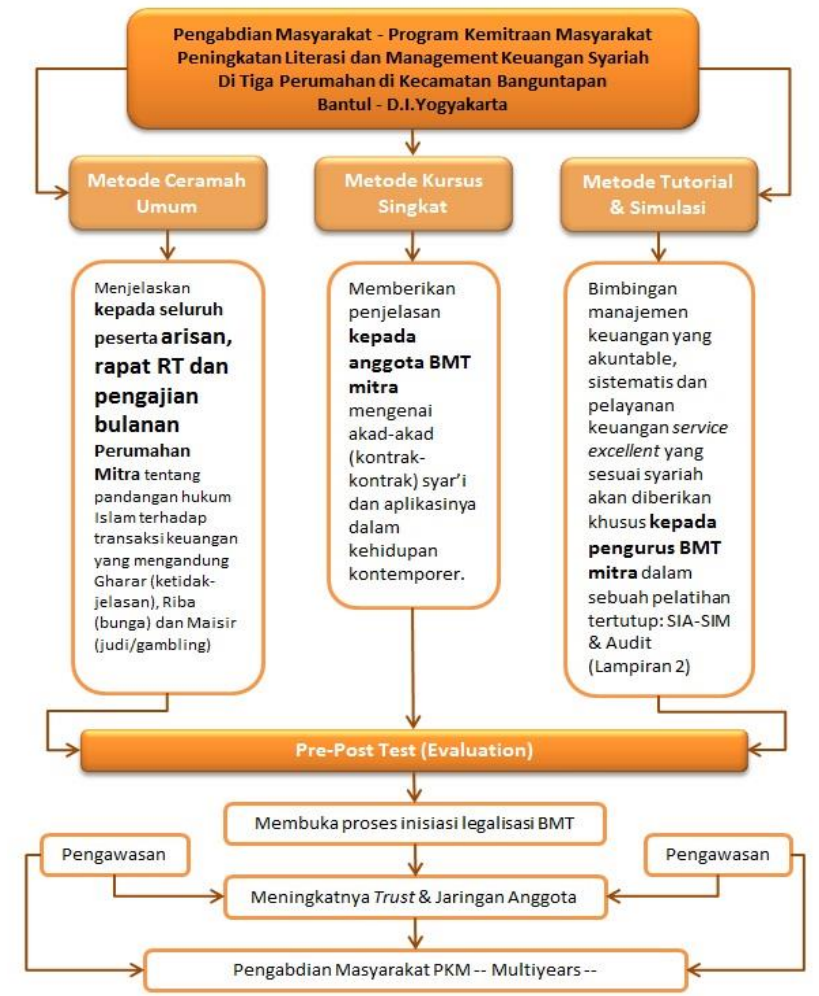

Figure 1. Method of Service Implementation

The target of this PKM program is economically productive communities, namely people in housing in Banguntapan sub-district, Bantul DIY who have just established BMT covering aspects 
of marketing/socialization and management and accounting information systems (small businesses). The aim of the program is to develop an economically independent community with high literacy on syar'i transactions. Business partners in this program are BMTs that have just been established with a residential mosque base, namely BMT Sakinah, BMT Al-Anbiya and BMT Al-Huda. In detail, the targets of this PKM are the administrators, managers and members of the new BMT around the housing estate. In observation, because BMT is still new, its management is very limited. Of the three combined housing BMTs, the total is only around 23 people.

\section{RESULTS AND DISCUSSION}

The following will describe the results and discussion of the program to increase literacy and Islamic financial management through the one housing area program one BMT in Banguntapan District, Bantul, Yogyakarta:

\section{Workshop for Partner BMT Members}

The target of this workshop is BMT Mitra members, namely BMT Sakinah (Puri Sakinah 2 Housing), BMT Al-Anbiya (Pesona Banguntapan Kotagede Housing), and BMT Al-Huda (Graha Banguntapan Housing). The partner BMTs are beginner BMTs that have just been initiated and are managed by recitation mothers in residential areas. So that Islamic financial literacy and specifically about BMT management still need help. Thus, as part of efforts to improve sharia financial literacy in general, a special workshop was held for BMT Mitra members in order to educate sharia contracts in the economy and motivate BMT Mitra members to keep the spirit to do good deeds through the economic sector. Because Islam is a value and a system that only talks about aqidah, but also enters into all lines of life,

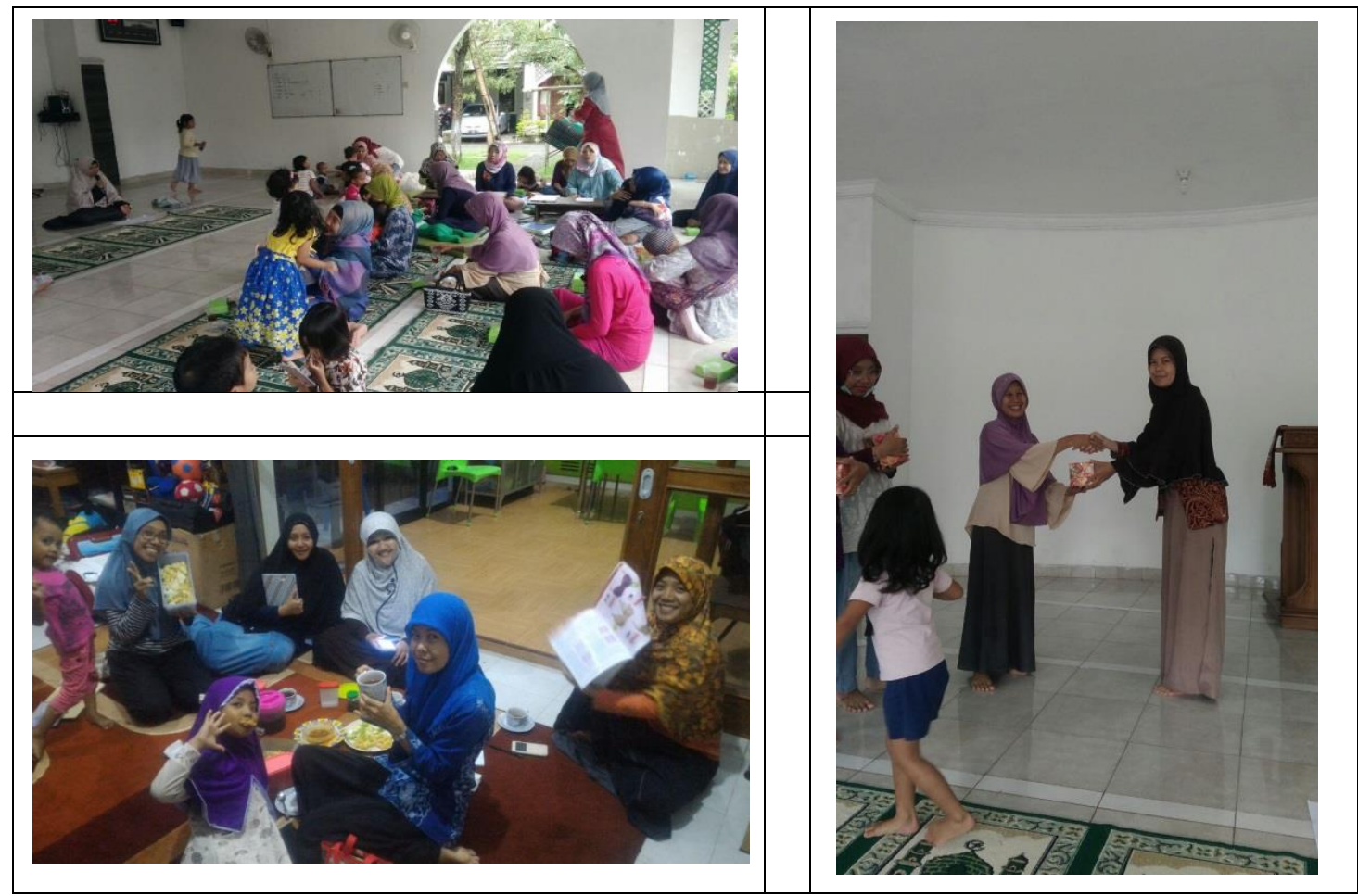

Figure 1. Sharia Financial Literacy Workhsop at Puri As-Sakinah Housing

This workshop was held at the Puri As-Sakinah Housing Mosque, and was attended by members from 3 housing BMTs in Banguntapan. This workshop was highly appreciated by the members of the housing BMT, because it was very useful for increasing Islamic financial literacy as well as a momentum for togetherness between the management and members of the BMT in the three housing estates.

\section{Training for BMT Partner Managers}

The next community service activity is training for BMT Mitra management. The training of the three BMTs in these three housing estates is important because the management of 
the housing BMTs still has inadequate management. Based on the survey of problems, BMT policy decisions are still under sharia advisory and management is still centered on one person. In addition, the low Islamic financial literacy of the administrators and residents of housing makes the number of BMT membership low. Thus, this community service training focuses on 3 training materials, including:

a. Understanding Sharia Transaction Contracts

Materials on sharia transaction contracts were delivered such as wadiah (savings), murabahah (sales and purchase contracts), mudharabah (profit sharing), musyarakah (profit sharing) and ijarah (leasing).

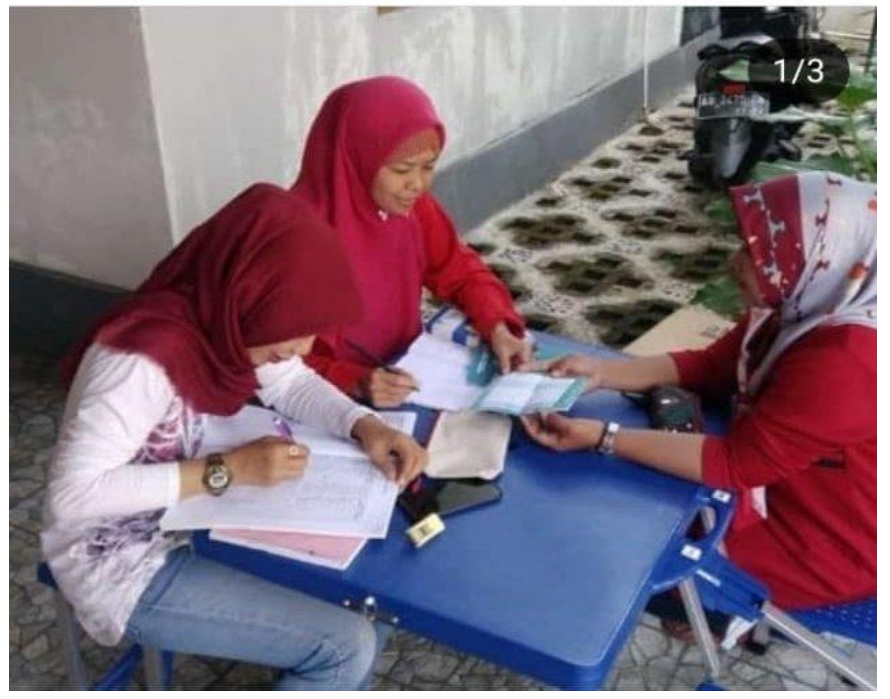

Figure 2. Sharia Transaction Contract Training Process

b. BMT Management

The focus of the BMT management material is more on how the steps must be prepared so that the housing BMT can obtain legality and become a legal entity. So that it can expand its market share which is not only focused on housing areas, but can also expand outside housing.

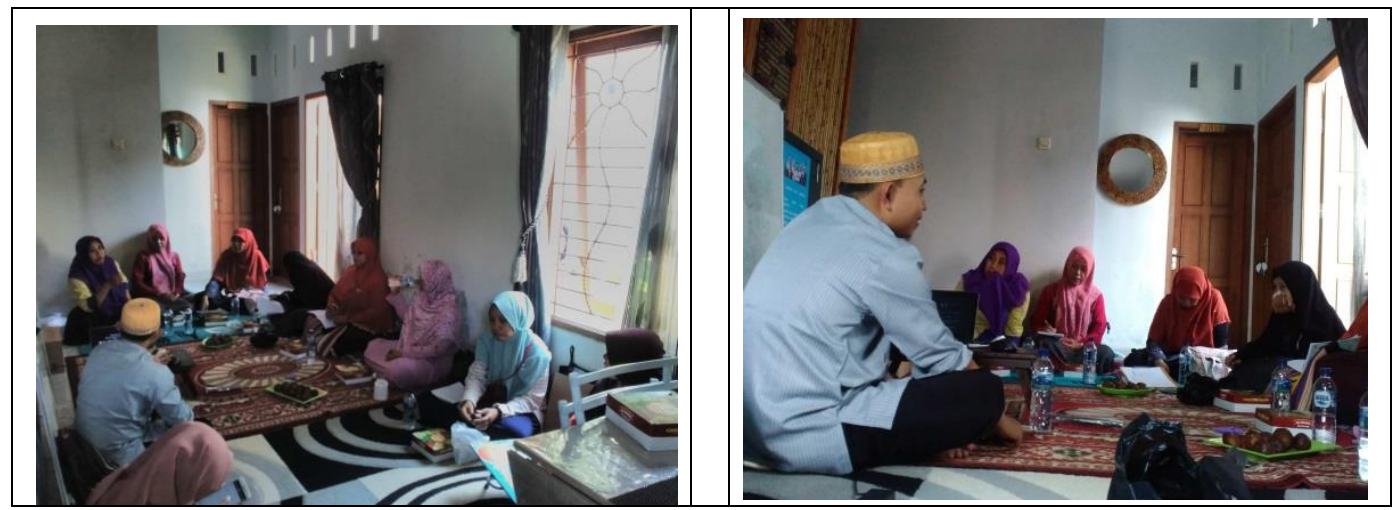

Figure 3. BMT Management Training

c. BMT Financial Accounting

BMT Financial accounting training is more focused on improving BMT's internal finances so that they are more accountable, transparent and can be managed professionally. 


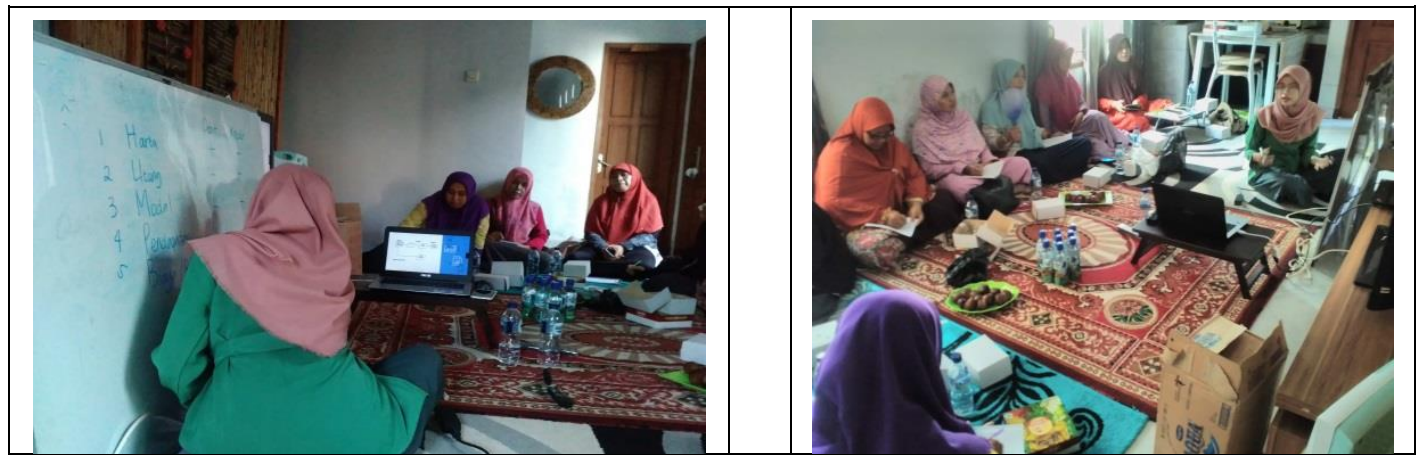

Figure 4. BMT Financial Accounting Training

\section{BMT Software Procurement}

In order to facilitate the operations of BMT Mitra, in this community service there is also a provision of software as well as a direct dissertation training that is directly mentored by the relatively advanced BMT management.

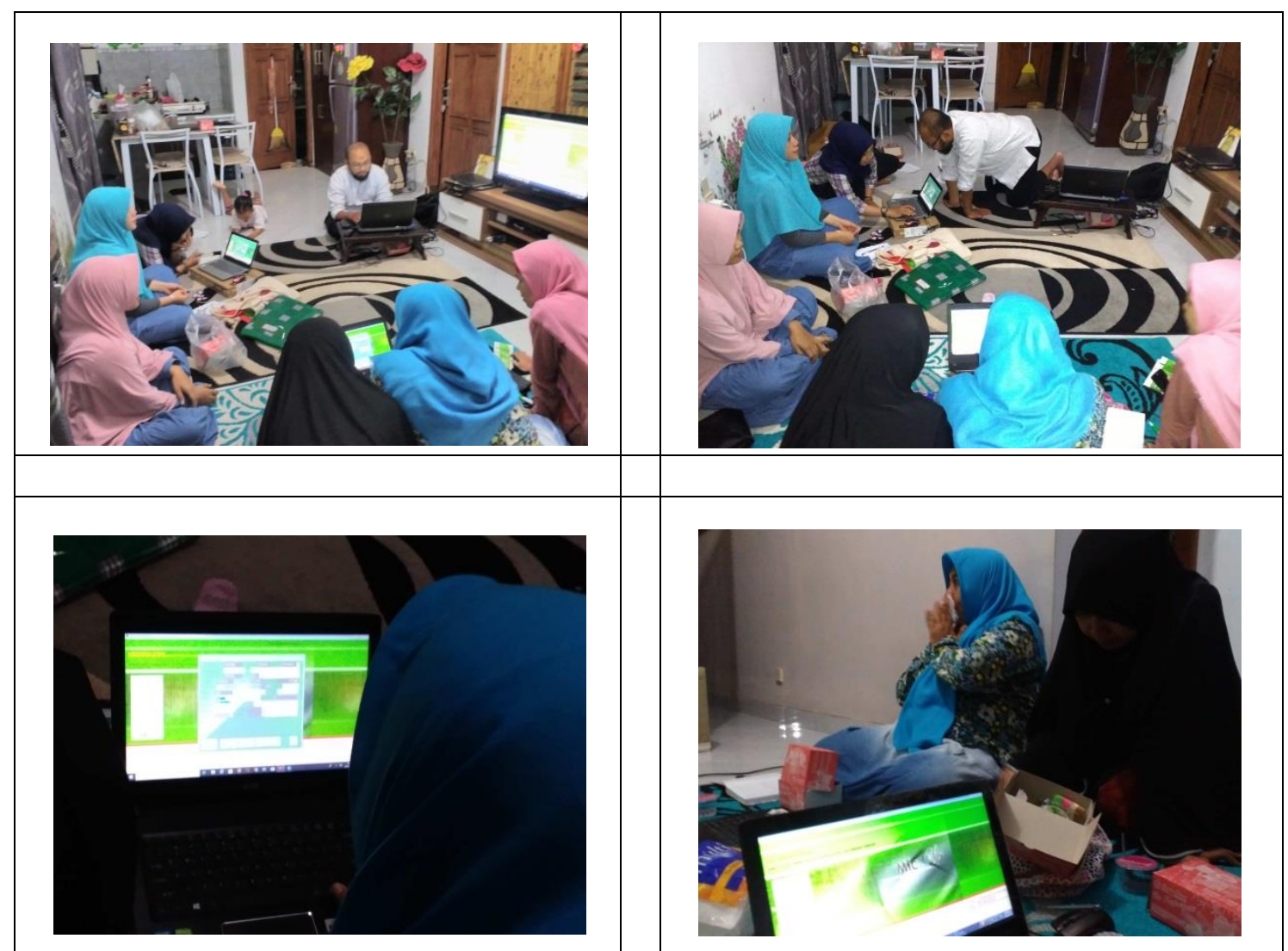

Figure 5. BMT Software practical training

\section{CONCLUSION}

Community service programs can be well organized and run smoothly in accordance with the activity plans that have been prepared. This activity received a very good response as evidenced by the activeness of the administrators and managers of three BMTs in three housing estates in the South Banguntapan neighborhood in participating in BMT financial management training by not leaving the place before the study time ended. This program even provides special assistance and is able to provide BMT financial system software so that it can be managed in an accountable, 
professional and transparent manner. Coupled with regular assistance from software providers to train BMT administrators and managers, BMT Sakinah (Puri Sakinah 2 Housing), BMT Al-Anbiya (Pesona Banguntapan Kotagede Housing), and BMT Al-Huda (Graha Banguntapan housing).

\section{ACKNOWLEDGMENT}

1. Research, Publication, and Community Service Institute (LP3M) Universitas Muhammadiyah Yogyakarta.

2. Puri Sakinah Banguntapan Housing

3. Housing Enchantment Banguntapan Kotagede

4. Graha Banguntapan Housing

5. BMT Partners (BMT Sakinah, BMT Al-Anbiya, and BMT Al-Huda)

\section{REFERENCES}

Bantul, P. (2017). Banguntapan District Profile. Retrieved January 18, 2018, from Banguntapan District: kec-banguntapan.bantulkab.go.id/hal/profile

Huston, S. (2010). Measuring Financial Literacy. The Journal of Consumer Affairs, 4(2).

Adiwarman Azwar Karim, History of Islamic Economic Thought, third edition, (Jakarta : PT Raja Grafindo Persada, 2006)

Lusardi, A., \& Olivia, S. (2007). Financial Literacy and Retirement Preparedness: Evidence and Implications for Financial Education Program.

Mendari, USA (2013, October). Financial Literacy Levels Among STIE Musi Students, Economica Journal, 9 (2), 2.

OJK. (2016). Publication Report of the National Survey of Indonesian Financial Literacy and Inclusion. Retrieved January 12, 2016, from the Financial Services Authority: www.sikapiuangmu.ojk.go.id.

OJK. (2016, January). Publication Report of the 2016 Indonesian Financial Literacy and Inclusion National Survey. Retrieved January 12, 2016, from the Financial Services Authority: www.sikapiuangmu.ojk.go.id

Development, Economics Study Program. (2017, June). Renstra for Leading Research and Community Service FEB-UMY Development Economics Study Program, Report. 